\title{
Evaluation of Proximate Composition and Sensory Quality Acceptability of Ethiopian Flat Bread (Injera) Prepared from Composite Flour, Blend of Maize, Teff and Sorghum
}

\author{
Melaku Tafese Awulachew \\ Food Science and Nutrition Research, Ethiopian Institute of Agricultural research, Kulumsa Agricultural Research Center, Assela, Ethiopia
}

\section{Email address:}

Melakutafese12@gmail.com

\section{To cite this article:}

Melaku Tafese Awulachew. Evaluation of Proximate Composition and Sensory Quality Acceptability of Ethiopian Flat Bread (Injera) Prepared from Composite Flour, Blend of Maize, Teff and Sorghum. International Journal of Food Engineering and Technology.

Vol. 4, No. 2, 2020, pp. 18-24. doi: 10.11648/j.ijfet.20200402.12

Received: September 17, 2019; Accepted: October 22, 2019; Published: September 3, 2020

\begin{abstract}
The aim of this study was to investigate the effect of composite teff flour blend with sorghum and maize. Cereal based foods are eaten either in fermented or unfermented form depending on the habit or tradition of a given community. In Ethiopia, the most widely consumed fermented food by young children and adults alike are Injera, which is a thin, flat, traditional fermented pancake. However, depending on the agro-ecology of the area concerned (highlands versus lowlands), different cereal blends are used to make Injera. Teff has remained an important crop to Ethiopian farmers for several reasons, namely: the price for its grain and straw are higher than other major cereals; the crop performs better than other cereals under moisture stress and waterlogged conditions; its grain can be stored for a long period of time without being attacked by weevils; there is no disease epidemic that has threatened its performance. The method of processing of Injera from its raw materials to the final product involves preparing and mixing the ingredients to dough, which is fermented and subsequently thinned to a batter. The batter is then baked by pouring onto a hot griddle in a thin layer to develop a characteristic color, flavor and texture. Composite teff flour blend with sorghum and maize had brought effect in different manner with regard to nutritional composition and sensory acceptability. Moreover, it is preferable and healthy formulation especially for people whose life style is sedentary and not energy demanding.
\end{abstract}

Keywords: Composite Flour, Proximate Composition, Injera, Sensory Analysis

\section{Introduction}

Cereal based foods are eaten either in fermented or unfermented form depending on the habit or tradition of a given community. In Ethiopia, the most widely consumed fermented food by young children and adults alike is Injera, which is a thin, flat, traditional fermented pancake. However, depending on the agro-ecology of the area concerned (highlands versus lowlands), different cereal blends are used to make Injera, [1]. Cereal grains constitute a major source of dietary nutrients all over the world; although, cereals are deficient in some basic components (e.g. essential aminoacids), fermentation may be the most simple and economical way of improving their nutritional value, sensory properties, and functional qualities [2].

Teff, Eragrostis teff, belived to have originated in Ethiopia
[3]. Currently, teff is cultivated as a forage crop in countries like Australia, India, Kenya and the Republic of South Africa with limited human consumption in the USA [4]. The crop is the second most widely produced and consumed cereal in Ethiopia next to maize [5]. Teff has remained an important crop to Ethiopian farmers for several reasons, namely: the price for its grain and straw are higher than other major cereals; the crop performs better than other cereals under moisture stress and waterlogged conditions; its grain can be stored for a long period of time without being attacked by weevils; there is no disease epidemic that has threatened its performance [6].

Teff flour is used to prepare Injera, while the straw provides a nutritious feed for cattle or can be used as a house plastering material. According to CSA data, over the past few years cultivation of teff ranked first in terms of area coverage 
(accounting for $28 \%$ of the area) and is second to maize in terms of volume of production among cereals, accounting for about $20 \%$ of the total produce in the category [5].

A report shows that 16 out of the 20 released improved varieties of teff were developed by Debre Zeit Agricultural Research Center (DZARC), [7]. According to the same source, previously released varieties have not been widely accepted by farmers because of their color, despite higher yield levels. However, because of its acceptable color and yield, the recently released Quncho (DZ-Cr-387) variety has become popular particularly around the Ada'a area, which is one of the known teff growing localities in the country.

Teff is the one of the high-priced cereals grown in Ethiopia and following the prevalence of high food price inflation in the country in 2008 , the price of teff has also experienced a huge increase in recent years [7]. White teff, for instance, on average has increased by $200 \%$ from 2005 to 2010 . The price of teff took off, starting in May and June of 2008 when wheat and maize prices also peaked. It has increased from Birr 593 per quintal in April to Birr 810 per quintal in May and then to Birr 931 per quintal in June of the same year. Since then, it has become a grain that fetches a high price per quintal, albeit less per hectare (on account of its inferior yields) than wheat or chickpeas. Currently the price of one quintal of teff is estimated between birr xxx and yyy depending on the variety of the grain and harvest season of the year [5]. Similar price increases were observed for mixed and red teff as well [7].

In Ethiopia Injera is made from teff flour whose preparation consists of two stages of natural fermentation that lasts for about 1 to 3 days depending on fermentation temperatures. The only required ingredients to prepare Injera are teff flour and water [8]. The method of processing of Injera from its raw materials to the final product involves preparing and mixing the ingredients to dough, which is fermented and subsequently thinned to a batter. The batter is then baked by pouring onto a hot griddle in a thin layer to develop a characteristic color, flavor and texture. This study was intended to evaluate the effect of composite teff flour blended with sorghum and maize flours on fermentation $\mathrm{pH}$ kinetics, sensory acceptability, and macro-nutritional quality of Injera from the blend.

\section{Materials and Method}

\subsection{Sample Collection and Preparation}

The samples, Sorghum \& Maize were obtained from Melkasa Agricultural Research Center and white teff (Kuncho) from Debrezeit Agricultural Research Center. These sampling sites were chosen purposely as it was possible to get widely consumed varieties among our society. All preventive and precautionary measures were taken while collecting the grain samples to avoid adventitious contamination including wearing gloves, using clean plastic poly ethylene bags, etc.

All samples of teff, sorghum and maize were taken separately to be winnowed, cleaned, and then stored in an air tight closed polyethylene bags so that it was used for the entire study. The samples were divided in to two portions in which one portion was used for the preparation of 10 different experimental Injeras so that proximate nutritional composition, and sensory acceptability determinations were conducted, and the second portion was used to prepare 3 different optimized batter formulations for the determination of $\mathrm{pH}$ kinetics and to prepare 4 different optimized Injera formulations. All analytical determinations were conducted in duplicate.

\subsection{Study Site}

Experiments were conducted at the Food Science and Nutrition research laboratory centers under the Ethiopian agricultural research institute.

\subsection{Proportional Product Formulation}

$\mathrm{F} 1=$ control $(100 \%$ teff $)$

$(\mathrm{F} 2)=0.554$ (teff), 0.373 (sorghum) and 0.073 (maize)

$\mathrm{F} 3=0.500$ (teff), 0.307 (sorghum) and 0.193 (maize)

\subsection{Preparation of fermentation Starter (Ersho)}

$50 \mathrm{~g}$ of flour from each of the 10 blended samples, $30 \mathrm{ml}$ of home Ersho (about $2 \%$, estimated by taking $100 \mathrm{ml}$ of home Ersho, weighing initially, after evaporation to dryness and calculating the percentage) and $50 \mathrm{ml}$ of clean water was used to prepare each of the fermentation starter of all the 10 experimental trials that also includes the 3 formulations resulted from optimization. The fermentation starter was then become ready for use after 10 hours of fermentation and was used for the preparation of the main dough.

\subsection{Dough Preparation}

After 10 hours of preparation, the whole Ersho was mixed with $351 \mathrm{~g}$ of flour followed by the addition of $200 \mathrm{ml}$ of clean water for further mixing. The prepared thick dough was kept covered for 72 hours at room temperature to allow fermentation (primary fermentation) and then about $70 \mathrm{ml}$ of supernatant was discarded followed by dough thinning through the addition of $200 \mathrm{ml}$ clean water which this was then left covered for 15 minutes to allow further fermentation. The so called Abscit, which serves as a binder, was prepared with a ratio of 1:3 (thin dough: water) by boiling on a hot oven (about 120g) and then cooled to a temperature of about $43^{\circ} \mathrm{C}$. It was then added fully onto the thinned batter, mixed carefully and left for 1 hour up until it rises (secondary fermentation) that became ready for baking to prepare Injera.

With the use of Mesti, a small container, about $450 \mathrm{ml}$ of the final batter was poured on to hot clay griddle in a circular motion working toward the centre from outside. After 2 to 3 minutes of cooking on a traditional baking equipment (Metad), the Injera was removed and stored inside a short cylindrical bowl called Mesob on and over clean poly bag after cooling. 


\subsection{Sun Drying and Grinding of Dried Injera}

The prepared Injera of all the trials was properly sundried by spreading onto a flat clean plastic sheet, was then ground into a dry fine sample with the use of grinder mill previously used and finally collected and stored in to a clean poly bag for further laboratory analysis.

\subsection{Determination of Proximate Composition Analysis}

The proximate composition i.e., crude protein, crude fat, moisture, carbohydrate content, energy, Ash content and crude fiber analysis was determined based on their respective standard procedures [9-13].

\subsubsection{Crude Protein}

Crude protein is total nitrogen multiplied by protein factor. It is expressed in $\mathrm{g}$ per $100 \mathrm{~g}$ sample. Total nitrogen content includes nitrogen primarily from proteins and to a lesser extent from all organic nitrogen containing non-protein substances. For practical purposes, non-protein nitrogen is assumed to be of little significance. The crude protein was determined by kjeldahl method [9-13]. The method is based on the digestion of proteins and other organic food components in the sample with sulfuric acid in the presence of catalyst e.g. sodium or potassium sulfate to release nitrogen from protein and retain it as ammonium salt. Ammonia gas is liberated upon addition of excess alkali (concentrated sodium hydroxide) and is distilled into a boric acid solution to form ammonium-borate complex. The ammonia liberated from the complex is titrated with standardised hydrochloric acid. The amount of nitrogen in the sample is determined from the milligram equivalent of the acid used. Crude protein is determined by multiplying the nitrogen content with a conversion factor specific to the food matrix.

\subsubsection{Crude Fat}

The fat content of Injera samples had been evaluated by using semi-continous solvent extraction method (Sohxlet method) following the official methods of AOAC, $2000[9$, $10]$.

\subsubsection{Ash Content}

Ash content refers to the total mineral residue left after incineration of organic matter. It has no nutritional significance per se, but the value for ash is a useful check in summing up the proximate composition of food and a measure of its mineral content. It is expressed as $g$ ash per $100 \mathrm{~g}$ sample. The ash content of the samples was determined by gravimetric method [9-12]. The method involves oxidation of all organic matter by incineration in a furnace at a specified temperature $\left(<550^{\circ} \mathrm{C}\right)$ Ashing above $650^{\circ} \mathrm{C}$ will volatilise inorganic salts like alkali chloride and a portion of ash will fuse and enclose some carbon, preventing them from being ignited. The residue left after incineration is the ash content of the sample.

\subsubsection{Moisture Content}

The moisture content of the samples was determined by air oven drying method [9-12]. Moisture in this method refers to the amount of free water and volatile substances that are lost by drying the food under controlled temperature in an air oven. It is expressed in $\mathrm{g}$ per $100 \mathrm{~g}$ sample. The method is based on the drying of food sample under controlled temperature until constant weight is obtained. Moisture content is required to express the nutrient content per dry weight basis. In some foods, moisture is used to indicate their quality. Standard values of moisture are indicated in food notification or regulation.

\subsubsection{Total Carbohydrate Content}

Total carbohydrate content of foods samples had calculated by difference, rather than analysed directly. Under this approach, the other constituents in the food (protein, fat, water, alcohol, ash) are determined individually, summed and subtracted from the total weight of the food. This is referred to as total carbohydrate by difference and is calculated by the following formula, $[9,10]$ :

Total carbohydrate content $=100-($ weight in grams $[$ protein + fat + water + ash + alcohol] in $100 \mathrm{~g}$ of food $)=100 \%-$ $(\%$ moisture $+\%$ protein $+\%$ fat $+\%$ ash $)$

\subsubsection{Energy}

The total energy content of the food samples was determined by the sum of nine times fat content, four times total carbohydrate content $(\mathrm{CHO})$ content and four times protein content [9, 10]. Those the total energy of food samples had calculated as: Total energy in $\mathrm{Kcal} / 100 \mathrm{~g}=9[\%$ fat content $]+4[\% \mathrm{CHO}$ content $+\%$ protein content $]$.

\subsubsection{Crude Fiber}

Fat-free organic substances in feeding stuffs which are insoluble in acid and alkaline media. Crude fibre is a measure of the quantity of indigestible cellulose, pentosans, lignin, and other components of this type in present foods. It is the residue of plant materials remaining after solvent extraction followed by digestion with dilute acid and alkali. These components have little food value but provide the bulk necessary for proper peristaltic action in the intestinal tract. Crude fiber content was determined by the standard method $[9,10]$. A sample - de-fatted where necessary - is treated successively with boiling solutions of sulphuric acid and potassium hydroxide of specified concentrations. The residue is separated by filtration on a sintered-glass filter washed, dried, weighed and ashed within a range of $475 \ldots 500^{\circ} \mathrm{C}$. The loss of weight resulting from ashing corresponds to the crude fibre present in the sample.

\subsection{Data Analysis}

Statistical Product and Service Solution, SPSS version 20 software packages were used to analyze experimental results of the experimental trials and of the optimized formulations 
through the use of one way ANOVA in comparing means of the 10 trials, and two-way ANOVA in comparing sensory acceptability means of the four optimized formulations for three different days. All the data analysis was conducted at a significance level of $\mathrm{p}<0.05$ and "Duncan's multiple comparison" was followed for separation of significantly different means.

\section{Results}

\subsection{Proximate Composition}

Table 1. Proximate composition of raw ingredients.

\begin{tabular}{|c|c|c|c|c|c|c|c|}
\hline Ingredients & Crude Protein (\%) & Crude Fat (\%) & Crude fiber (\%) & Total Ash (\%) & Moisture content (\%) & Total CHO (\%) & $\begin{array}{l}\text { Total Energy } \\
\text { (Kcal/100g) }\end{array}$ \\
\hline Teff & $12.24 \pm 0.06^{\mathrm{a}}$ & $2.69 \pm 0.03^{\mathrm{a}}$ & $8.57 \pm 0.12^{\mathrm{a}}$ & $2.93 \pm 0.06^{\mathrm{a}}$ & $9.69 \pm 0.04^{\mathrm{a}}$ & $72.37 \pm 0.07^{\mathrm{a}}$ & $362.65 \pm 0.23^{\mathrm{a}}$ \\
\hline Sorghum & $15.06 \pm 0.10^{\mathrm{b}}$ & $3.69 \pm 0.08^{b}$ & $12.70 \pm 0.01^{\mathrm{b}}$ & $1.69 \pm 0.05^{\mathrm{b}}$ & $9.50 \pm 0.24^{\mathrm{a}}$ & $69.85 \pm 0.18^{b}$ & $372.83 \pm 0.38^{b}$ \\
\hline Maize & $9.92 \pm 0.09^{c}$ & $5.18 \pm 0.10^{\mathrm{c}}$ & $8.87 \pm 0.02^{\mathrm{a}}$ & $1.45 \pm 0.05^{\mathrm{c}}$ & $8.75 \pm 0.01^{\mathrm{b}}$ & $74.74 \pm 0.07^{\mathrm{c}}$ & $385.38 \pm 0.66^{\mathrm{c}}$ \\
\hline
\end{tabular}

*The data is expressed as mean \pm standard error on a dray weight basis and Any two means in the same column not followed by the same letters are significantly different at $(\mathrm{p}<0.05)$.

Table 2. Proximate composition of the 10 experimental trials.

\begin{tabular}{|c|c|c|c|c|c|}
\hline \multicolumn{6}{|l|}{ Recipe } \\
\hline Trials & Teff & Sorghum & Maize & Crude Protein (\%) & Crude fat (\%) \\
\hline Control (Trial 1) & 1.000 & 0.00 & 0.00 & $11.34 \pm 0.00^{\mathrm{ab}}$ & $1.79 \pm 0.03^{\mathrm{a}}$ \\
\hline Trial 2 & 0.833 & 0.083 & 0.083 & $12.02 \pm 0.10^{c}$ & $3.26 \pm 0.21^{\mathrm{fg}}$ \\
\hline Trial 3 & 0.75 & 0.25 & 0.000 & $14.22 \pm 0.10^{\text {ef }}$ & $2.94 \pm 0.16^{\mathrm{ef}}$ \\
\hline Trial 4 & 0.75 & 0.25 & 0.000 & $14.50 \pm 0.10^{\mathrm{f}}$ & $2.57 \pm 0.06^{\text {cde }}$ \\
\hline Trial 5 & 0.50 & 0.25 & 0.25 & $13.14 \pm 0.34^{\mathrm{d}}$ & $2.82 \pm 0.06^{\mathrm{de}}$ \\
\hline Trial 6 & 0.50 & 0.50 & 0.00 & $14.73 \pm 0.10^{f}$ & $2.54 \pm 0.08^{\text {cde }}$ \\
\hline Trial 8 & 0.75 & 0.00 & 0.25 & $11.69 \pm 0.24^{\mathrm{abc}}$ & $2.82 \pm 0.11^{\mathrm{de}}$ \\
\hline Trial 9 & 1.00 & 0.00 & 0.00 & $11.27 \pm 0.17^{\mathrm{a}}$ & $2.06 \pm 0.10^{\mathrm{ab}}$ \\
\hline rial 10 & 0.667 & 0.167 & 0.167 & $13.92 \pm 0.11^{\mathrm{e}}$ & $2.14 \pm 0.20^{\mathrm{ab}}$ \\
\hline
\end{tabular}

Table 2. Continued.

\begin{tabular}{lllll}
\hline Recipe & & & \\
\hline Trials & Crude fiber (\%) & Total ash (\%) & Moisture content (\%) & CHO (\%) \\
\hline Control (Trial 1) & $6.00 \pm 0.03^{\mathrm{b}}$ & $2.98 \pm 0.03^{\mathrm{g}}$ & $65.94 \pm 0.06^{\mathrm{d}}$ & $17.98 \pm 0.02^{\mathrm{i}}$ \\
Trial 2 & $9.29 \pm 0.01^{\mathrm{i}}$ & $2.59 \pm 0.02^{\mathrm{ef}}$ & $66.86 \pm 0.10^{\mathrm{f}}$ & $15.18 \pm 0.07^{\mathrm{g}}$ \\
Trial 3 & $7.17 \pm 0.03^{\mathrm{c}}$ & $2.74 \pm 0.01^{\mathrm{fg}}$ & $67.35 \pm 0.03^{\mathrm{g}}$ & $133.39 \pm 0.35^{\text {de }}$ \\
Trial 4 & $7.96 \pm 0.11^{\mathrm{f}}$ & $2.78 \pm 0.04^{\mathrm{fg}}$ & $66.31 \pm 0.02^{\mathrm{e}}$ & $137.98 \pm 1.37^{\mathrm{f}}$ \\
Trial 5 & $7.71 \pm 0.05^{\mathrm{e}}$ & $2.34 \pm 0.02^{\text {cde }}$ & $69.98 \pm 0.06^{\mathrm{j}}$ & $134.26 \pm 1.00^{\mathrm{e}}$ \\
Trial 6 & $9.52 \pm 0.04^{\mathrm{j}}$ & $2.51 \pm 0.01^{\text {def }}$ & $73.25 \pm 0.16^{\mathrm{k}}$ & $11.74 \pm 0.23^{\mathrm{b}}$ \\
Trial 7 & $7.54 \pm 0.02^{\mathrm{d}}$ & $2.19 \pm 0.07^{\mathrm{bc}}$ & $69.37 \pm 0.16^{\mathrm{i}}$ & $7.14 \pm 0.05^{\mathrm{a}}$ \\
Trial 8 & $5.65 \pm 0.08^{\mathrm{a}}$ & $2.58 \pm 0.03^{\mathrm{ef}}$ & $65.37 \pm 0.14^{\mathrm{c}}$ & $13.39 \pm 0.36^{\mathrm{de}}$ \\
Trial 9 & $7.95 \pm 0.11^{\mathrm{f}}$ & $2.94 \pm 0.03^{\mathrm{g}}$ & $66.25 \pm 0.23^{\mathrm{de}}$ & $124.86 \pm 0.10^{\mathrm{b}}$ \\
rial 10 & $8.15 \pm 0.04^{\mathrm{g}}$ & $1.99 \pm 0.18^{\mathrm{b}}$ & $69.59 \pm 0.04^{\mathrm{i}}$ & $110.36 \pm 0.54^{\mathrm{a}}$ \\
\hline
\end{tabular}

The data is expressed as mean \pm standard error on a dray weight basis and any two means in the same column not followed by the same letters are significantly different at $(\mathrm{p}<0.05)$ and any one means in the same column followed by the same letters are similar.

\subsection{Sensory Acceptability of the Experimental Trials}

The mean sensory acceptability results of the 10 experimental trials for color, taste, texture, appearance, odor and over all acceptability obtained from the experiment was as in (Table 3 ) and had been used for formulation optimization.

Table 3. Sensory acceptability of the experimental trials.

\begin{tabular}{|c|c|c|c|c|c|c|c|c|c|}
\hline \multicolumn{10}{|l|}{ Recipe } \\
\hline Trials & Teff & Sorghum & Maize & Color & Taste & Texture & Odor & Appearance & $\begin{array}{l}\text { Overall } \\
\text { acceptability }\end{array}$ \\
\hline Trial 1 (control) & 1.000 & 0.00 & 0.00 & $4.00 \pm 0.23^{\mathrm{ab}}$ & $3.53 \pm 0.22^{\text {bcd }}$ & $2.79 \pm 0.26^{\mathrm{abc}}$ & $3.68 \pm 1.06$ & $2.74 \pm 0.30^{\mathrm{ab}}$ & $3.37 \pm 0.19^{\text {bcd }}$ \\
\hline Trial 2 & 0.833 & 0.083 & 0.083 & $4.68 \pm 0.14^{\mathrm{c}}$ & $3.79 \pm 0.18^{\mathrm{cd}}$ & $4.16 \pm 0.18^{f}$ & $3.63 \pm 0.83$ & $4.05 \pm 0.18^{\mathrm{d}}$ & $4.16 \pm 0.14^{\mathrm{e}}$ \\
\hline Trial 3 & 0.75 & 0.25 & 0.000 & $3.84 \pm 0.23^{\mathrm{a}}$ & $3.16 \pm 0.22^{\mathrm{abc}}$ & $3.05 \pm 0.20^{\mathrm{abcd}}$ & $3.32 \pm 1.11$ & $3.05 \pm 0.27^{\mathrm{ab}}$ & $3.16 \pm 0.21^{\mathrm{bc}}$ \\
\hline Trial 4 & 0.75 & 0.25 & 0.000 & $3.86 \pm 0.22^{\mathrm{a}}$ & $3.67 \pm 0.20^{\mathrm{cd}}$ & $3.67 \pm 0.23^{\mathrm{def}}$ & $3.43 \pm 0.98$ & $3.38 \pm 0.22^{\mathrm{abcd}}$ & $3.52 \pm 0.20^{\mathrm{bcd}}$ \\
\hline
\end{tabular}




\begin{tabular}{|c|c|c|c|c|c|c|c|c|c|}
\hline Recipe & & & & & & & & & \\
\hline Trials & Teff & Sorghum & Maize & Color & Taste & Texture & Odor & Appearance & $\begin{array}{l}\text { Overall } \\
\text { acceptability }\end{array}$ \\
\hline Trial 5 & 0.50 & 0.25 & 0.25 & $3.90 \pm 0.21^{\mathrm{a}}$ & $2.86 \pm 0.19^{\mathrm{ab}}$ & $2.57 \pm 0.24^{\mathrm{a}}$ & $2.71 \pm 1.19$ & $2.71 \pm 0.23^{\mathrm{a}}$ & $2.43 \pm 0.20^{\mathrm{a}}$ \\
\hline Trial 6 & 0.50 & 0.50 & 0.00 & $4.24 \pm 0.15^{\mathrm{abc}}$ & $3.86 \pm 0.19^{\mathrm{d}}$ & $3.71 \pm 0.23^{\mathrm{def}}$ & $3.38 \pm 1.07$ & $3.52 \pm 0.24^{\mathrm{bcd}}$ & $3.71 \pm 0.23^{\text {cde }}$ \\
\hline Trial 7 & 0.583 & 0.083 & 0.333 & $4.19 \pm 0.19^{\mathrm{abc}}$ & $3.19 \pm 0.23^{\mathrm{abcd}}$ & $2.63 \pm 0.32^{\mathrm{ab}}$ & $3.38 \pm 0.96$ & $3.13 \pm 0.24^{\mathrm{abc}}$ & $3.00 \pm 0.23^{\mathrm{ab}}$ \\
\hline Trial 8 & 0.75 & 0.00 & 0.25 & $4.25 \pm 0.17^{\mathrm{abc}}$ & $3.31 \pm 0.24^{\mathrm{abcd}}$ & $3.44 \pm 0.24^{\text {def }}$ & $3.38 \pm 1.03$ & $3.44 \pm 0.20^{\mathrm{abcd}}$ & $3.25 \pm 0.17^{\mathrm{bcd}}$ \\
\hline Trial 9 & 1.00 & 0.00 & 0.00 & $3.69 \pm 0.22^{\mathrm{a}}$ & $3.88 \pm 0.22^{\mathrm{d}}$ & $3.81 \pm 0.25^{\mathrm{ef}}$ & $3.69 \pm 0.87$ & $3.44 \pm 0.30^{\mathrm{abcd}}$ & $3.69 \pm 0.20^{\text {cde }}$ \\
\hline Trial 10 & 0.667 & 0.167 & 0.167 & $4.12 \pm 0.21^{\mathrm{abc}}$ & $3.12 \pm 0.17^{\mathrm{abc}}$ & $3.35 \pm 0.21^{\text {bcde }}$ & $3.53 \pm 0.87$ & $3.47 \pm 0.23^{\mathrm{abcd}}$ & $3.41 \pm 0.17^{\mathrm{bcd}}$ \\
\hline
\end{tabular}

*The data is expressed as mean \pm standard error and Any two means in the same column not followed by the same letters are significantly different at ( $<<0.05$ ) and any one means in the same column followed by same letters are similar.

\subsection{Sensory Acceptability of the Optimized Formulations}

Table 4. Mean sensory acceptability of the optimized formulations due to variation of days.

\begin{tabular}{llllll}
\hline \multicolumn{6}{l}{ Effect of variation of days on the sensory acceptability of Injera (second main effect) } \\
\hline Day & Color & Taste & Texture & Odor & Appearance \\
\hline Day 1 & $4.01 \pm 0.10^{\mathrm{b}}$ & $3.56 \pm 0.12^{\mathrm{b}}$ & $3.59 \pm 0.11^{\mathrm{b}}$ & $3.4 \pm 0.12^{\mathrm{b}}$ & $3.73 \pm 0.11^{\mathrm{b}}$ \\
Day 2 & $3.73 \pm 0.10^{\mathrm{a}}$ & $3.20 \pm 0.12^{\mathrm{a}}$ & $3.14 \pm 0.11^{\mathrm{a}}$ & $3.36 \pm 0.12^{\mathrm{b}}$ & $3.59 \pm 0.10^{\mathrm{b}}$ \\
Day 3 & $3.63 \pm 0.10^{\mathrm{a}}$ & $3.04 \pm 0.12^{\mathrm{a}}$ & $3.08 \pm 0.11^{\mathrm{a}}$ & $2.83 \pm 0.12^{\mathrm{a}}$ & $3.15 \pm 0.11^{\mathrm{a}}$ \\
\hline
\end{tabular}

*The data is expressed as mean \pm standard error and Any two means in the same column not followed by the same letters are significantly different and any two means in the same column followed by the same letters are similar means at $(\mathrm{p}<0.05)$.

The mean color, taste, texture, odor, appearance and over all acceptability of the three optimized formulations were similar with the control formulation (F 1) in the first day that was all of them for all of the six parameters had a very liked score while the scores for all the sensory parameters with the exception of odor were significantly different after the first day (day 2) and after the second day (day 3) for all the formulations including the control at a significance level of $p<0.05$ but the formulations were still liked by the panelists even after three days storage of the Injera samples for all the six sensory parameters (Table 4), thus the Injera prepared from the optimized formulations can be eaten for three days being liked in a comparable manner with $100 \%$ teff Injera.

Table 5. Mean sensory acceptability of the optimized formulations due to the interaction of the main effects.

\begin{tabular}{|c|c|c|c|c|c|c|c|}
\hline \multicolumn{8}{|c|}{ Effect on sensory acceptability of Injera due to the interaction of change of formulation and days (factor from interaction) } \\
\hline Day & Form. & Color & Taste & Texture & Odor & Appearance & Overall acceptability \\
\hline \multirow{3}{*}{ Day 1} & F1 & $4.30 \pm 0.21^{\mathrm{a}}$ & $3.85 \pm 0.24^{\mathrm{a}}$ & $4.10 \pm 0.22^{\mathrm{a}}$ & $3.45 \pm 0.24^{\mathrm{a}}$ & $4.00 \pm 0.22^{\mathrm{a}}$ & $3.90 \pm 0.21^{\mathrm{a}}$ \\
\hline & $\mathrm{F} 2$ & $4.20 \pm 0.21^{\mathrm{a}}$ & $3.35 \pm 0.24^{\mathrm{a}}$ & $3.60 \pm 0.22^{\mathrm{a}}$ & $3.40 \pm 0.24^{\mathrm{a}}$ & $4.10 \pm 0.22^{\mathrm{a}}$ & $3.75 \pm 0.21^{\mathrm{a}}$ \\
\hline & F3 & $3.60 \pm 0.21^{\mathrm{a}}$ & $3.45 \pm 0.24^{\mathrm{a}}$ & $3.30 \pm 0.22^{\mathrm{a}}$ & $3.55 \pm 0.24^{\mathrm{a}}$ & $3.40 \pm 0.22^{\mathrm{a}}$ & $3.20 \pm 0.21^{\mathrm{a}}$ \\
\hline \multirow{3}{*}{ Day 2} & F1 & $3.50 \pm 0.21^{\mathrm{a}}$ & $3.35 \pm 0.24^{\mathrm{a}}$ & $3.50 \pm 0.22^{\mathrm{a}}$ & $3.25 \pm 0.24^{\mathrm{a}}$ & $3.40 \pm 0.22^{\mathrm{a}}$ & $3.50 \pm 0.21^{\mathrm{a}}$ \\
\hline & $\mathrm{F} 2$ & $3.90 \pm 0.21^{\mathrm{a}}$ & $3.25 \pm 0.24^{\mathrm{a}}$ & $3.20 \pm 0.22^{\mathrm{a}}$ & $3.50 \pm 0.24^{\mathrm{a}}$ & $3.50 \pm 0.22^{\mathrm{a}}$ & $3.25 \pm 0.21^{\mathrm{a}}$ \\
\hline & F3 & $3.60 \pm 0.21^{\mathrm{a}}$ & $3.10 \pm 0.24^{\mathrm{a}}$ & $3.20 \pm 0.22^{\mathrm{a}}$ & $3.35 \pm 0.24^{\mathrm{a}}$ & $3.25 \pm 0.22^{\mathrm{a}}$ & $3.15 \pm 0.21^{\mathrm{a}}$ \\
\hline \multirow[t]{2}{*}{ Day 3} & $\mathrm{~F} 2$ & $3.65 \pm 0.21^{\mathrm{a}}$ & $3.00 \pm 0.24^{\mathrm{a}}$ & $3.05 \pm 0.22^{\mathrm{a}}$ & $2.65 \pm 0.24^{\mathrm{a}}$ & $3.00 \pm 0.22^{\mathrm{a}}$ & $3.00 \pm 0.21^{\mathrm{a}}$ \\
\hline & F3 & $3.85 \pm 0.21^{\mathrm{a}}$ & $3.00 \pm 0.24^{\mathrm{a}}$ & $2.75 \pm 0.22^{\mathrm{a}}$ & $3.05 \pm 0.24^{\mathrm{a}}$ & $3.30 \pm 0.22^{\mathrm{a}}$ & $3.10 \pm 0.21^{\mathrm{a}}$ \\
\hline
\end{tabular}

*The data is expressed as mean \pm standard error and Any two means in the same column not followed by the same letters are significantly different and any two means in the same column followed by the same letters are similar means at $(\mathrm{p}<0.05)$.

The mean sensory acceptability response of all the six parameters were not affected significantly at a $p<0.05$ due to the effect from the interaction variation of both factors (Table 5), thus the interaction of the main effects had no significant effect on the sensory parameters.

The mean odor response of the Injera's from all the formulations was shown to range from 2.83 to 3.40 after the first day of its preparation to the third day which was all liked (Table 4). The mean odor response due to the interaction of the two factors (Table 5, different days and different formulations) was shown to range from 2.65 to 3.55 (from liked to very liked). When the grand mean (3.21=liked) was compared with the control F1 (3.45=very liked) of all the three days, the odor response was still liked even after three days storage of Injera samples, after compositing or blending of teff (formulation variation) and after interaction of the two factors.

The mean appearance response of the Injera's from all the formulations was shown to range from 3.15 to 3.73 after the first day of its preparation to the third day which was from liked to very liked (Table 4). The mean appearance response due to the interaction of the two factors (Table 5, different days and different formulations) was shown to range from 3.00 to 4.10 (from liked to very liked). When the grand mean (3.39=liked) was compared with the control F1 (4.00=very liked) of all the three days, the appearance response was still liked even after three days storage of Injera samples, after compositing or blending of teff (formulation variation) and after interaction of the two factors.

The mean over all acceptability response of the Injera's from all the formulations was shown to range from 3.1 to 
3.59 after the first day of its preparation to the third day which was from liked to very liked (Table 4). The mean over all acceptability response due to the interaction of the two factors (Table 5, different days and different formulations) was shown to range from 3.00 to

3.90 (from liked to very liked). When the grand mean (3.33=liked) was compared with the control F1 $(3.90=$ very liked) of all the three days, the overall acceptability response was still liked even after three days storage of Injera samples, after compositing or blending of teff (formulation variation) and after interaction of the two factors.

\section{Discussion}

The mean crude protein content of the experimental trials varies from each other depending on the type and amount of ingredients incorporated in each of the recipe of the trials. Most of the experimental trials containing sorghum had shown the highest protein content while the experimental trials containing maize had shown the least protein content as compared to the control experimental trial (trial1). The first reason for the highest and least protein content was associated with the type and quantity of the ingredients. That was the protein content of sorghum was the highest while that of maize was the least out of the three. Thus experimental trials containing sorghum (trial 6) had relatively shown the highest protein content while those containing maize (trial 7) had shown the least protein content. The other reason might be associated with the blending that flour compositing affects fermentation kinetics [1] and fermentation affects protein availability [14].

The mean fat content of the experimental trials vary from each other depending on the type and amount of ingredients incorporated in each of the recipe of the trials. All of the experimental trials containing sorghum and maize had shown the highest fat content as compared to the control (trial1). Those experimental trials containing maize had shown even higher result as compared to those containing sorghum. The reason is associated with the highest fat content $(5.18 \%) \&$ least moisture content $(8.75 \%)$ as compared to the least fat composition $(2.69 \%)$ and the highest moisture content $(9.69 \%)$ of the control teff.

The mean crude fiber content of the experimental trials varies from each other depending on the type and amount of ingredients incorporated in each of the recipe of the trials. The crude fiber content of the experimental trials containing sorghum had shown the highest fiber content as compared to the control and those containing maize. The first reason is associated with the highest fiber content of sorghum $(12.70 \%)$ as compared to teff $(8.57 \%)$ and maize $(8.87 \%)$.

The mean total ash content of some of the experimental trials varies depending on the type and amount of ingredients incorporated in each of the recipe of the trials. Experimental trials containing significant amount of teff had the highest and similar total ash content as that of the control (trial 1) than the other experimental trials. The reason is due to the highest total ash content of teff $(2.93 \%)$ as compared to sorghum (1.69\%) and maize (1.45\%).

Throughout the mean moisture content of the 10 experimental trials, those experimental trials containing significant amount of sorghum in the recipe had shown the highest moisture content as compared to the moisture content of the control (trial1) which might be due to enhanced water absorption capacity of the recipes when sorghum was incorporated in relatively higher amount. The moisture content of those experimental trials whose teff proportion was the highest had shown the least moisture content as compared to the control. The reason for the other situation might be associated with a better water holding capacity of the experimental trials containing significant amount of sorghum in the recipe, also the blending and processing effect might also have impact on the moisture content. The mean total carbohydrate content of the experimental trials varies from each other depending on the type and amount of ingredients incorporated in each of the recipe of the trials, and depending on their moisture, total ash, protein \& fat content.

The panelist varies significantly at significance level of $\mathrm{p}<0.05$ in a group of three among the 10 experimental trials, all the formulations were liked more than average by the panelists, similar to that of the control trial 1 (4.00). Those formulations having maize in the recipe had shown a relatively maximum color response Trial $2=4.68$ suggesting that the ingredient maize had good coloring effect.

The mean crude protein composition of the optimized formulations including the control ranges from $11.34 \%-16.00 \%$ and the values for optimized formulations had shown to have maximum crude protein composition $(\mathrm{F} 2=16 \%, \mathrm{~F} 3=15.81 \%)$ as compared to the control F1 (11.34\%). When these values were compared with the predicted value of $14.06 \%$, the values of optimized formulations were close to the predicted crude protein composition.

The mean crude fat composition of the optimized formulations including the control ranges from $1.79 \%-3.01 \%$ and the values for the optimized formulations had shown to have maximum crude fat composition $(\mathrm{F} 2=3.01 \%, \mathrm{~F} 3=3.01 \%)$ as compared to the control F1 (1.79\%). When these values were compared with the predicted value of $2.64 \%$, the values of optimized formulations were close to the predicted crude fat composition. When we compare these results in relation to their recipe, all the optimized formulations had shown maximal crude fat composition as compared to the control due to the presence of maize in their recipe. In addition all the mean crude fat composition of the optimized formulations were similar and all were significantly different from the control at the significance level of $p<0.05$.

The mean crude fiber composition of the optimized formulations including the control ranges from $6.00 \%$ $8.66 \%$. When the crude fiber composition of the three optimized formulations were compared with control, maximal crude fiber content had been shown owing to the blending especially incorporation of sorghum in their recipe and as compared to the predicted value $(8.42 \%)$ the fiber content of the formulations was closer and improved. Thus in 
relation to our objective criteria to maximize fiber composition, the optimized formulations had met the target.

The total ash composition of the optimized formulations including the control ranges from $2.22 \%-2.98 \%$. The total ash composition of F3 (2.22\%) which was the least and those of F2 $(2.43 \%)$ higher than F3 but lower than F1 (2.98\%). Those formulations containing larger amount of teff had shown relatively higher total ash content.

The mean moisture content of the optimized formulations including the control ranges from $60.98 \%-68.37 \%$. The moisture content of F2 $(68.37 \%)$ was the maximum which might be due to its high sorghum proportion in its recipe and F3 (60.98\%) was the least which might be due to its high maize proportion in its recipe.

The mean total carbohydrate composition of the optimized formulations including the control ranges from $10.33 \%$ $18.02 \%$. The carbohydrate composition of F3 (18.02\%) was the maximum which might be due to its high maize proportion in its recipe and F2 (10.33\%) was the least which might be due to its high sorghum proportion in its recipe.

\section{Conclusion}

Injera prepared from the composite flour blend of teff with sorghum and maize had brought effect in different ways as compared to the Injera prepared from $100 \%$ teff as follows:

With regard to sensory acceptability, the acceptability of Injera from $100 \%$ teff was superior in preference over Injeras from the three optimized formulations for its taste, texture, appearance and over all acceptability; however, similarity was found out for color \& odor responses. But all the three optimized formulations were liked while the control was very liked for taste, texture, appearance \& odor responses within three days.

With regard to the macro-nutritional quality, the protein, fat and crude fiber content of the Injeras from the three optimized formulations were increased by up to $5 \%, 1 \%$ and $2.66 \%$, respectively as compared to the Injera prepared from $100 \%$ teff (control). The carbohydrate content of the Injera prepared from the optimized formulations was decreased from $8 \%$ lower $(\mathrm{F} 2=10.33 \%)$ as compared to the $100 \%$ teff Injera $(\mathrm{F} 1=17.98 \%)$ with exception of Injera prepared from $(\mathrm{F} 3=18.02 \%)$ which had similar or un-affected carbohydrate content as compared to the control Injera. Concerning total energy value, the energy value for formulation F3 was increased by $11.43 \mathrm{Kcal} / 100 \mathrm{~g} \& 28.98 \mathrm{Kcal} / 100 \mathrm{~g}$ respectively while that of $F 2(132.39 \mathrm{Kcal} / 100 \mathrm{~g})$ remains un-affected significantly due to flour composite blending as compared to the control F1 $(133.39 \mathrm{Kcal} / 100 \mathrm{~g})$.

Formulation two, F2 (teff $=0.554$, sorghum $=0.372$ and maize $=0.073)$ is the recommended recipe in terms of decreased energy value (from $\mathrm{F} 1=133.39 \mathrm{Kcal} / 100 \mathrm{~g}$ to $\mathrm{F} 2=132.39 \mathrm{Kcal}$ ), increased fiber content (from $\mathrm{F} 1=6.00 \%$ to $\mathrm{F} 2=8.47 \%$ ), in terms of sensory acceptability even if F1 was very liked F2 was also liked and this sensory acceptability value can be improved by shortening fermentation period from three days up to one and half day. Formulation F2 is preferable and healthy especially for people whose life style is sedentary and not energy demanding in any case.

\section{References}

[1] Baye, K., Claire, M. R., Christèle, I. V., Isabelle, R., JeanPierre, G. (2012) Influence of flour blend composition on fermentation kinetics and phytate hydrolysis of sourdough used to make injera, ELSEVIER Journal of food chemistry, 1.

[2] Blandino, A., Al-Aseeri, M. E., Pandiella, S. S., Cantero, D., and Webb C. (2002). Cereal-based fermented foods and beverages, Food research international, ELSEVIER, 528-530.

[3] Vavilov, N. I. (1951). The Origin, Variation, Immunity and Breeding of Cultivated Plants. Roland Press, New York, (Translated from the Russian by K. Starrchester).

[4] Costanza, S. H., Dewet, J. M. and Harlan, J. R. (1979). Literature review and numerical taxonomy of Ergarostis tef (t'ef). - Econ. Bot. 33: $413-424$.

[5] CSA. (2010/11). Agricultural Sample Survey: Area Planed and Production of Major Crops, Meher Season. Volume I.

[6] Ketema, S. (1989). Production trends, germplasm resources, breeding, and varietal improvement of small millets, with special emphasis on Tef in Ethiopia. In Seetharam A., Riley K. W. and Harinarayana G. (Eds.) Small millets in Global Agriculture. IDRC, Oxford and IBH Co. India.

[7] Bekabil, F., Befekadu, B., Rupert, S. and Tareke, B. (2011). Strengthening the teff value chain in Ethiopia, Agricultural Transformation Agency, a diagnostic report, pp. 1-5 \& 24.

[8] Zewdu, A. (2012). Improvement of injera shelf life through the use of chemical preservatives, African journal of food, agriculture, nutrition and development, pp. 1-4.

[9] AOAC, (2000). Association of Offical and Analytical Chemists, Official Methods of Analysis, Washington D. C. 17th ed., Vol. 2

[10] Horwitz W (2000) (editor). Official Method of Analysis of AOAC International. 17th Edition. AOAC International, Maryland, USA.

[11] Greenfield H and Southgate DAT (1992). Food Composition Data: Production, Management and Use. Elsevier Applied Science, UK.

[12] Kirk RS and Sawyer R (1991). Pearson's Composition and Chemical Analysis of Foods, 9th Edition. Longman Scientific \& Technical, Essex, England.

[13] WHO (1973). Report of a Joint FAO/WHO Ad Hoc Expert Committee on Energy and Protein Requirements, WHO Technical Report Series No. 522, WHO, Geneva.

[14] Hamad, A. M., \& Fields, M. L. (1979). Evaluation of protein quality and available lysine of germinated and ungerminated cereals. Journalof Food Science, 44, 456-459. 